\title{
Factors Associated with Death among Tuberculosis Patients in Dakar
}

\author{
Moustapha Diop ${ }^{1 *}$, Papa Samba Ba ${ }^{1}$, Jean Augustin Diegane Tine ${ }^{2}$, Ndèye Maguette Fall ${ }^{3}$, \\ Tracie Youbong1, Mouhamadou Ndiaye ${ }^{4}$, Ndèye Mouminatou Mbaye4, \\ Mouhamed Bouye Nestor Diatta ${ }^{4}$, Alassane Sarr ${ }^{3}$, Sokhna Walo Ndiaye ${ }^{5}$, Ibrahima Cisse ${ }^{6}$, \\ Louise Fortes Degenonvo 3 , Abdourahmane Niang4, Adama Faye ${ }^{2}$, Moussa Seydi ${ }^{3}$
}

\author{
${ }^{1}$ Department of Infectious and Tropical Diseases, Dakar Principal Hospital, Dakar, Senegal \\ ${ }^{2}$ Health and Development Institute, Cheikh Anta Diop University of Dakar, Dakar, Senegal \\ ${ }^{3}$ Department of Infectious and Tropical Diseases, FANN Teaching Hospital, Dakar, Senegal \\ ${ }^{4}$ Department of Pulmonology, Dakar Principal Hospital, Dakar, Senegal \\ ${ }^{5}$ Faculty of Medicine and Odontology, Cheikh Anta Diop University of Dakar, Dakar, Senegal \\ ${ }^{6}$ Private Institute for Training and Research in Medicine, Dakar, Senegal \\ Email: *mouztaphandm@gmail.com
}

How to cite this paper: Diop, M., Ba, P.S., Tine, J.A.D., Fall, N.M., Youbong, T., Ndiaye, M., Mbaye, N.M., Diatta, M.B.N., Sarr, A., Ndiaye, S.W., Cisse, I., Degenonvo, L.F., Niang, A., Faye, A. and Seydi, M. (2021) Factors Associated with Death among Tuberculosis Patients in Dakar. Advances in Infectious Diseases, 11, 122-139. https://doi.org/10.4236/aid.2021.112013

Received: February 21, 2021

Accepted: April 16, 2021

Published: April 19, 2021

Copyright $\odot 2021$ by author(s) and Scientific Research Publishing Inc. This work is licensed under the Creative Commons Attribution International License (CC BY 4.0).

http://creativecommons.org/licenses/by/4.0/

\begin{abstract}
Introduction-Objective: Tuberculosis (TB) is the leading cause of death from a single infectious agent worldwide. The predictors of mortality due to TB are rarely evaluated in Senegal. The aim of our study was to identify factors associated with related TB death in two treatment centers in Dakar, Senegal. Method: We conducted a prospective descriptive-analytical study dealing with TB patients followed in the Department of Infectious and Tropical Diseases at FANN Teaching Hospital and Dakar Principal Hospital and in the Department of Pulmonology at Dakar Principal Hospital from March $1^{\text {st }}, 2019$ to February $29^{\text {th }}, 2020$. Univariate and multivariate logistic regressions were performed to identify the associated factors of death. Results: Two hundred eighty-two patients in the Department of Infectious and Tropical Diseases at FANN teaching hospital (57\%), in the Department of Infectious and Tropical Diseases at Dakar Principal Hospital (31\%), and in the Department of Pulmonology at Dakar Principal Hospital (12\%) were included in the study. The mean age was $39 \pm 16$ years and the male to female ratio was 2.2. Isolated pulmonary $\mathrm{TB}$, isolated extrapulmonary $\mathrm{TB}$, and both pulmonary and extrapulmonary TB were present in $33.3 \%, 30.5 \%$ and $36.2 \%$ of cases, respectively. Twenty-two patients died, corresponding to a mortality rate of $7.8 \%$. Factors independently associated with death were age $\geq 60$ years $(26.2$ [3.6 - 191.2]) compared to 16 - 40 years' age group, HIV infection (7.2 [1.4 36.9]), neurological localization of TB (13.19 [3.2 - 54.3]), and hemoglobin level $<10 \mathrm{~g} / \mathrm{dl}(5.5[1.3-23.9])$. Conclusion: Tuberculosis remains a fatal
\end{abstract}


disease despite therapeutic advances. Better knowledge of associated factors of death from TB may help to reduce its mortality.

\section{Keywords}

Tuberculosis, Death, Associated Factors, Dakar

\section{Introduction}

Tuberculosis (TB) is an infectious and chronic endemo-epidemic disease with human-to-human transmission through the respiratory tract with the organism Mycobacterium tuberculosis. It is a global public health issue, mainly in developing countries. According to the World Health Organization (WHO), the number of people infected with TB was around 10 million in 2018 [1] [2]. The annual incidence of tuberculosis varies widely from one country to another, ranging from less than 5 to 500 cases per 100,000 per year with an average of around 130 cases per 100,000 per year [2]. TB is among the top 10 causes of death in the world and the leading cause of death from a single infectious agent ranking above HIV/AIDS. In 2018 the number of people dying from TB was estimated at 1.2 million in those who are HIV negative and 251,000 in those co-infected with HIV. More than $95 \%$ of these deaths occur in medium or low-income countries [1] [2]. To deal with the high morbidity and mortality of TB, the WHO has adopted a response plan called "End TB" with the aims to reduce the incidence by $80 \%$ and death rate by $90 \%$ by the year 2030 [3]. Senegal is engaged in this strategy in the fight against this global public health issue. A National Health Plan against Tuberculosis (NHPT) was set up to reduce the morbi-mortality rate of TB. In this practical approach, the Senegalese authorities have created centers for early diagnose and treatment of $\mathrm{TB}$ to ensure testing and treatment of $\mathrm{TB}$ according to the national guidelines. Despite these important measures, in 2017, the NHPT reported an incidence of 122 new cases per 100,000. All categories of TB were included with a testing rate of $60 \%$ and a mortality rate up to 18 deaths per 100,000 [4]. Studies focusing on associated factors of deaths among patients infected with TB in Senegal are not very common, and they often deal with retrospective data and particular groups, such as HIV patients [5]. These are some of the reasons why we conducted this study to assess the different factors associated with death among patients infected with TB in two health care centers in Dakar.

\section{Materials and Methods}

\subsection{Patients and Study Design}

A prospective descriptive analytical study was conducted, covering the period from March $1^{\text {st }} 2019$ to February $29^{\text {th }} 2020$. Our study population included all patients treated for TB in the following centers: the Department of Infectious and Tropical Diseases of Dakar Principal Hospital, the Department of Pulmo- 
nology of Dakar Principal Hospital, and the Department of Infectious and Tropical Diseases of FANN Teaching Hospital. All patients with bacteriologically confirmed or clinically diagnosed TB, who were at least 16 years of age, were included in the study. TB was confirmed by sputum smear microscopy for acid fast bacilli, Gene Xpert MTB/RIF essay, or Lowenstein Johnson medium culture of specimen. Patients unwilling to participate in the study or unavailable during the survey were not included. We excluded from the study the patients who were initially included without being bacteriologically confirmed in which late results of paraclinical investigations conclude to another disease than TB.

\subsection{Data Collection}

Data were collected from individual interviews with patients, medical records, and TB register of HNPT. After a literature review, a questionnaire was created and tested. Trained investigators were in charge to collect data, such as socio-demographic information (including age, gender, school attendance, level of education), date of hospitalization, department of hospitalization, medical backgrounds, lifestyle (including alcohol consumption, smoking status, marital status), clinical features, $\mathrm{x}$-ray and laboratory data, TB disease categories, final TB diagnosis, number of hospital days, and treatment outcome (mainly focusing on mortality).

\subsection{Study Definitions}

Some operational definitions were adopted to facilitate data analysis. According to the site of the disease, three categories of TB were defined: isolated pulmonary tuberculosis (IPT) (only the lungs were affected), isolated extrapulmonary tuberculosis (IET) (sites other than the lungs were affected) or both (pulmonary and extrapulmonary TB infection). Long-term fever was defined as a fever that was evolving for at least one month. Hyperleukocytosis was defined as white blood cells count $>12,000$ cells $/ \mathrm{mm}^{3}$, thrombocytopenia was defined as platelets count $<150,000$ cells $/ \mathrm{mm}^{3}$, severe anemia was defined as a hemoglobin rate $<10$ $\mathrm{g} / \mathrm{dl}$, and severe hyponatremia was defined as a serum sodium concentration $<$ $130 \mathrm{mmol} / \mathrm{L}$.

New TB cases were defined as patients who were diagnosed with TB and never received TB treatment before or had received TB treatment for less than 1 month. Relapse TB patients were defined as patients who were previously treated for $\mathrm{TB}$, were declared cured or treatment completed at the end of their most recent course of TB treatment, and are now diagnosed with a recurrent episode of TB (either a true relapse or a new episode of TB caused by reinfection).

Patients restarting treatment were defined as those who have already received anti-TB drugs and have been lost to follow-up for 2 months or more and returned with evolving symptoms of TB.

\subsection{Data Management and Statistical Analysis}

Data were recorded in EPI INFO software (version 7.2.2.6), exported to Excel 
(version 15.13.3), and analyzed using $\mathrm{R}$ software (version 3.4.1). According to their distribution, quantitative variables were represented using either means \pm standard deviations (SD) or medians and their interquartile ranges (IQR). Qualitative variables were represented using frequency and percentages. After checking their distribution normality and the variances homogeneity, the means were compared using either Student's t-test or Wilcoxon Mann Whitney test. The proportions were compared using Pearson chi-squared test, Pearson's Chi-squared test with Yates' continuity correction, or Fisher's exact test. To identify the factors associated with death among TB patients, we performed a univariate logistic regression then a multivariate logistic regression to calculate the adjusted odds ratios (aOR) and their respective 95\% confidence intervals (95\% CI). All independent variables with a $\mathrm{p}$-value $<0.2$ in the univariate model were introduced in the multivariate model, and a backward stepwise method was used to generate the final model. Hosmer Lemeshow's adequation test and interactions checking between independent variables were used to validate the final model with $\mathrm{p}$-value $<0.05$. At the end of this procedure, the independent variables were significantly associated with death among TB patients when the CI 95\% of their adjusted OR exclude the number of 1 .

\subsection{Ethical Considerations}

Prior to the study, permission was obtained from the departmental heads at FANN and Dakar Principal Hospitals. Moreover, we obtained the consent of all the patients included in the study. Their confidentiality and anonymity were preserved, and adequate medical care and follow up were provided.

\section{Results}

During the study period, 282 patients infected with TB, all categories of TB, were enrolled and followed in the Department of Infectious and Tropical Diseases at FANN (57\%), the Department of Infectious and Tropical Diseases at Dakar Principal Hospital (31\%) and in the Department of Pulmonology at Dakar Principal Hospital (12\%). There were $181(64.2 \%)$ in-patients.

\subsection{Descriptive Study}

\subsubsection{Epidemiological Characteristics}

The epidemiological characteristics are represented in Table 1 . The mean age was $39 \pm 16$ years old and the male to female ratio was 2.2 .

\subsubsection{Clinical Characteristics}

The mean weight was $56 \pm 11 \mathrm{~kg}$ with an average of Body Mass Index (BMI) of $18.6 \pm 3.5 \mathrm{~kg} / \mathrm{m}^{2}$. The symptoms that were present are represented in Table 2 .

\subsubsection{Paraclinical Data}

Chest x-rays were performed in 187 (66.3\%) patients and showed abnormalities in $150(80.2 \%)$. These abnormalities are represented in Figure 1. 


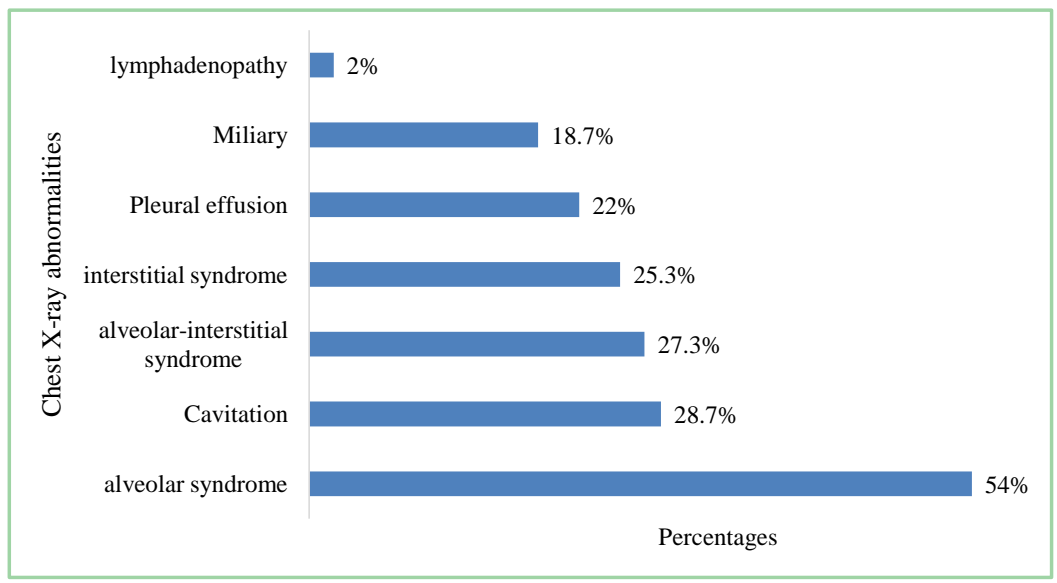

Figure 1. Distribution of TB patients according to their chest X-ray abnormalities in two health care centers in Dakar: 2019-2020 $(\mathrm{N}=150)$.

Table 1. Distribution of TB patients according to their epidemiological characteristics in two anti-TB treatment centers in Dakar: 2019-2020 $(\mathrm{N}=282)$.

\begin{tabular}{|c|c|c|}
\hline Variable & Frequency (n) & Percentages (\%) \\
\hline \multicolumn{3}{|l|}{ Groups of age (years) } \\
\hline$[16-40[$ & 157 & 55.7 \\
\hline$[40-65[$ & 88 & 31.2 \\
\hline$\geq 65$ & 37 & 13.1 \\
\hline \multicolumn{3}{|l|}{ Gender } \\
\hline Male & 194 & 68.8 \\
\hline Female & 88 & 31.2 \\
\hline \multicolumn{3}{|l|}{ Marital status } \\
\hline Married & 143 & 50.7 \\
\hline Single & 103 & 36.5 \\
\hline Divorced & 23 & 8.2 \\
\hline Widowed & 13 & 4.6 \\
\hline School attendance & 203 & 72 \\
\hline \multicolumn{3}{|l|}{ Educational level } \\
\hline Primary & 57 & 28.1 \\
\hline Secondary & 89 & 43.8 \\
\hline University & 57 & 28.1 \\
\hline History of TB contact & 73 & 25.9 \\
\hline History of TB & 24 & 8.5 \\
\hline HIV-positive patients & 80 & 28.4 \\
\hline High blood pressure & 22 & 7.8 \\
\hline Diabetes & 16 & 5.7 \\
\hline Chronic kidney disease & 3 & 1.1 \\
\hline \multicolumn{3}{|l|}{ Smokers } \\
\hline Current & 23 & 8.2 \\
\hline Former & 42 & 14.9 \\
\hline Alcohol consumption & 35 & 12.4 \\
\hline
\end{tabular}


Table 2. Distribution of TB patients according to the symptoms in two anti-TB treatment centers in Dakar: 2019-2020 ( $\mathrm{N}=282)$.

\begin{tabular}{ccc}
\hline Symptoms & Frequency & Percentages $(\%)$ \\
\hline Weight loss & 259 & 91.8 \\
Weakness & 253 & 89.7 \\
Loss of appetite & 248 & 87.9 \\
Long term fever & 231 & 81.9 \\
Coughing & 185 & 65.6 \\
Chest pain & 124 & 44 \\
Dyspnea & 122 & 43.3 \\
Headaches & 84 & 29.8 \\
Vomiting & 77 & 27.3 \\
Hemoptysis & 25 & 8.9 \\
\hline
\end{tabular}

Smear microscopy for acid fast bacilli and gene Xpert MTB/RIF essay of specimen were performed in $227(80.5 \%)$ and in $60(21.2 \%)$, respectively. The positivity rates were $80.5 \%$ for smear microscopy for acid fast bacilli and $66.7 \%$ for gene Xpert MTB/RIF essay. Lownstein Johnson medium culture was positive in 2 patients. The other laboratory results are represented in Table 3.

\subsubsection{Categories of TB}

Regarding the classification based on history of TB treatment, there were 257 (91.1\%) new TB cases, 24 (8.5\%) relapse cases, and 1 case of restarting TB treatment. Bacteriological evidence of TB was found in 147 (52.1\%). According to the sites of TB, 93 (33.3\%) had IPT, 86 (30.5\%) had IET, and both pulmonary and extrapulmonary TB infections were present in 102 (36.2\%). The main extrapulmonary localizations are represented in Figure 2.

\subsubsection{Evolutive Data}

Median duration of hospitalization was 17 days (IQT: 9 - 22 days). Of those enrolled in the study, 11 (3.9\%) had complications, such as thromboembolic disease (9), Klebsiella pneumoniae bacteremia (1) and neurocognitive disorders (1), during their follow up. Twenty-two (22) out of 282 patients died corresponding to mortality rate of $7.8 \%$.

\subsection{Analytical Study}

\subsubsection{Univariate Analysis}

\section{1) Epidemiological factors}

In univariate analysis, epidemiological factors significantly associated with death were advanced age $(p=0.003)$, widowed marital status $(p=0.001)$ and HIV infection status $(\mathrm{p}<0.001)$ (see Table 4$)$.

\section{2) Clinical factors}


In univariate analysis, IPT was a protective factor $(\mathrm{p}=0.04)$ and divided the the probability of death by 3 . However, the presence of both pulmonary and extra-pulmonary TB $(\mathrm{p}=0.005)$ and neurological localization of TB $(\mathrm{p}<0.001)$ were significantly associated with deaths (see Table 5).

\section{3) Paraclinical factors}

In the univariate analysis, biological abnormalities significantly associated with deaths were severe anemia $(\mathrm{p}<0.001)$, hyperleukocytosis $(\mathrm{p}=0.009)$, and severe hyponatremia $(\mathrm{p}=0.02)$ (see Table 6$)$.

\subsubsection{Multivariate Logistic Regression}

After adjustment for potential confounding factors, advanced age, co-infection with HIV, neurological localization of TB and severe anemia were independently associated with death (see Table 7). Probability of death was 26 times higher in patients over the age 60 than in patients between 16 to 40 . The probability was 7 times higher in HIV positive patients than in HIV negative patients, and it was 13 times higher in patients who had neurological TB localization. Patients who had severe anemia were 5 times more likely to die.

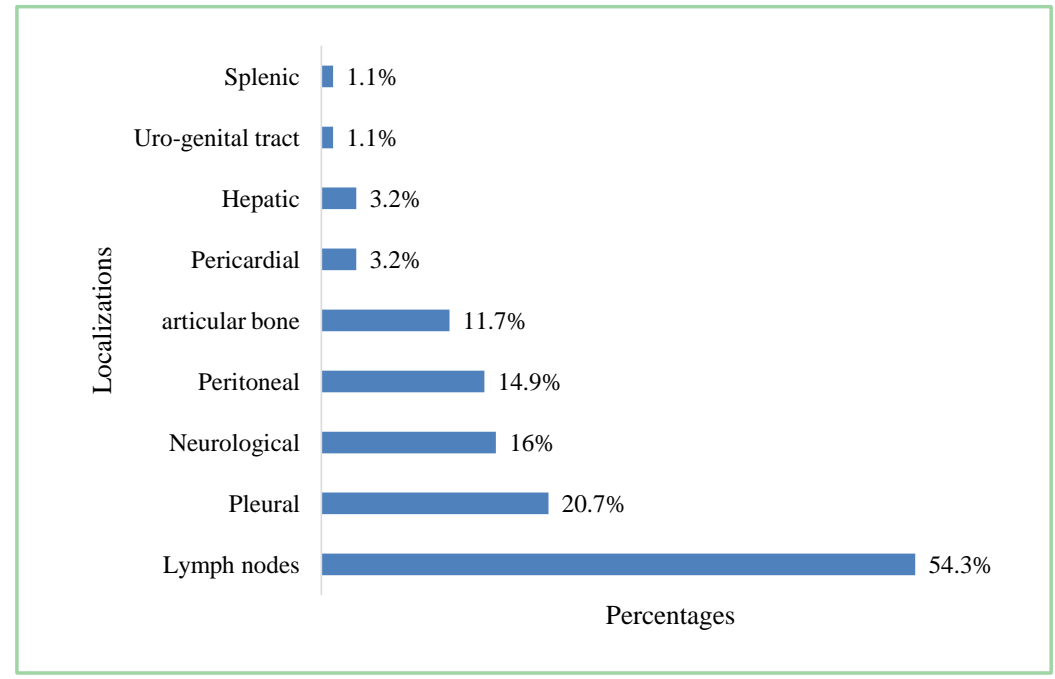

Figure 2. Distribution of TB patients according to the extrapulmonary TB localizations in two anti-TB treatment centers in Dakar: 2019-2020 ( $\mathrm{N}=188)$.

Table 3. Distribution of TB patients according to laboratory results in two anti-TB treatment centers in Dakar: 2019-2020 ( $=282)$.

\begin{tabular}{ccc}
\hline Laboratory data & Mean & Standard deviation \\
\hline White blood cells count $\left(\mathrm{cells} / \mathrm{mm}^{3}\right)$ & 7827 & 4199 \\
Hemoglobin $(\mathrm{g} / \mathrm{dl})$ & 10.5 & 2.3 \\
Platelets count $\left(\mathrm{cells} / \mathrm{mm}^{3}\right)$ & 377,679 & 260,288 \\
C-reactive Protein $(\mathrm{mg} / \mathrm{l})$ & 118.1 & 66.3 \\
Natremia $(\mathrm{mEq} / \mathrm{l})$ & 133.4 & 4.3 \\
ALT (IU/l) & 41.2 & 47.7 \\
\hline
\end{tabular}


Table 4. Distribution of deaths in TB patients according to their epidemiological characteristics in two anti-TB treatment centers in Dakar: 2019-2020 $(\mathrm{N}=282)$.

\begin{tabular}{|c|c|c|c|}
\hline \multirow{2}{*}{ Variables } & \multicolumn{2}{|c|}{ Death } & \multirow{2}{*}{$\mathrm{p}$} \\
\hline & Yes n (\%) & No $n(\%)$ & \\
\hline \multicolumn{4}{|c|}{ Age groups (years) } \\
\hline$[16-40[$ & $6(3.8)$ & $151(96.2)$ & - \\
\hline$[40-60[$ & $9(10.2)$ & $79(89.8)$ & 0.05 \\
\hline$\geq 60$ & $7(18.9)$ & $30(81.1)$ & 0.003 \\
\hline \multicolumn{4}{|l|}{ Gender } \\
\hline Male & $13(6.7)$ & $181(93.3)$ & \multirow{2}{*}{0.34} \\
\hline Female & $9(10.2)$ & $79(89.8))$ & \\
\hline \multicolumn{4}{|c|}{ Marital status } \\
\hline Singles & $3(2.9)$ & $100(97.1)$ & - \\
\hline Divorced & $2(8.7)$ & $21(91.3)$ & 0.22 \\
\hline Married & $13(9.1)$ & $130(90.9)$ & 0.06 \\
\hline Widows & $4(30.8)$ & $9(69.2)$ & 0.001 \\
\hline \multicolumn{4}{|c|}{ School attendance } \\
\hline Yes & $13(6.4)$ & $190(93.6)$ & \multirow{2}{*}{0.24} \\
\hline No & $9(11.4)$ & $70(88.6)$ & \\
\hline \multicolumn{4}{|l|}{ HIV infection } \\
\hline Yes & $14(17.3)$ & $67(82.7)$ & \multirow{2}{*}{$<0.001$} \\
\hline No & $8(4)$ & $193(96)$ & \\
\hline \multicolumn{4}{|c|}{ History of tuberculosis contact } \\
\hline Yes & $3(4.1)$ & $70(95.9)$ & \multirow{2}{*}{0.26} \\
\hline No & $19(9.1)$ & $190(90.1)$ & \\
\hline \multicolumn{4}{|c|}{ History of tuberculosis } \\
\hline Yes & $2(8.3)$ & $22(91.3)$ & \multirow{2}{*}{1} \\
\hline No & $20(7.8)$ & $238(92.2)$ & \\
\hline \multicolumn{4}{|c|}{ High Blood Pressure } \\
\hline Yes & $1(4.5 \%)$ & $21(95.5 \%)$ & \multirow{2}{*}{1} \\
\hline No & $21(8.1 \%)$ & $239(91.9 \%)$ & \\
\hline \multicolumn{4}{|l|}{ Diabetes } \\
\hline Yes & $3(18.8 \%)$ & $13(81.2 \%)$ & \multirow{2}{*}{0.12} \\
\hline No & $19(7.1 \%)$ & $247(92.9 \%)$ & \\
\hline \multicolumn{4}{|c|}{ Smoking statues } \\
\hline Never & $18(8.3)$ & $199(91.7)$ & - \\
\hline Active & $2(9.1)$ & $21(90.9)$ & 0.90 \\
\hline Former & $2(4.8)$ & $40(95.2)$ & 0.44 \\
\hline \multicolumn{4}{|c|}{ Alcohol consumption } \\
\hline Yes & $0(0)$ & $35(100)$ & \multirow{2}{*}{0.09} \\
\hline No & $22(8.9)$ & $225(91.1)$ & \\
\hline
\end{tabular}


Table 5. Distribution of deaths in TB patients according to their clinical forms in two anti-TB treatment centers in Dakar: 2019-2020 $(\mathrm{N}=282)$.

\begin{tabular}{|c|c|c|c|}
\hline \multirow{2}{*}{ Clinical forms } & \multicolumn{2}{|c|}{ Death } & \multirow{2}{*}{$\mathrm{p}$} \\
\hline & Yes N (\%) & No N (\%) & \\
\hline \multicolumn{4}{|l|}{ Final diagnosis } \\
\hline New TB cases & $20(7.8)$ & $237(92.2)$ & - \\
\hline Relapse TB cases & $2(8.3)$ & $22(91.7)$ & 0.9 \\
\hline Restart of TB treatment & $0(0)$ & $1(100)$ & 0.9 \\
\hline \multicolumn{4}{|l|}{ Isolate pulmonary $\mathrm{TB}$} \\
\hline Yes & $3(3.2)$ & $90(96.8)$ & \multirow[b]{2}{*}{0.04} \\
\hline No & $19(10.1)$ & $170(89.9)$ & \\
\hline \multicolumn{4}{|l|}{ Isolated extra pulmonary $\mathrm{TB}$} \\
\hline Yes & $5(5.8)$ & $81(94.2)$ & \multirow{2}{*}{0.4} \\
\hline No & $17(8.7)$ & $179(91.3)$ & \\
\hline \multicolumn{4}{|l|}{ IPT and IET } \\
\hline Yes & $14(13.6)$ & $89(86.4)$ & \multirow{2}{*}{0.005} \\
\hline No & $8(4.5)$ & $171(95.5)$ & \\
\hline \multicolumn{4}{|l|}{ Neurological localization } \\
\hline Yes & $9(31)$ & $20(69)$ & \multirow[b]{2}{*}{$<0.001$} \\
\hline No & $13(5.1)$ & $240(94.9)$ & \\
\hline \multicolumn{4}{|l|}{ Pericardial localization } \\
\hline Yes & $1(16.7)$ & $5(83.3)$ & \multirow[b]{2}{*}{0.39} \\
\hline No & $21(7.6)$ & $255(92.4)$ & \\
\hline \multicolumn{4}{|l|}{ Lymph node localization } \\
\hline Yes & $8(7.8)$ & $94(92.2)$ & \multirow{2}{*}{0.98} \\
\hline No & $14(7.8)$ & $166(92.2)$ & \\
\hline \multicolumn{4}{|l|}{ Pleural localization } \\
\hline Yes & $2(6.1)$ & $31(83.9)$ & \multirow[b]{2}{*}{1} \\
\hline No & $20(8)$ & $229(92)$ & \\
\hline \multicolumn{4}{|l|}{ Uro-genital localization } \\
\hline Yes & $1(50 \%)$ & $1(50 \%)$ & \multirow[b]{2}{*}{0.15} \\
\hline No & $21(7.5 \%)$ & $259(86 \%)$ & \\
\hline \multicolumn{4}{|l|}{ Peritoneal localization } \\
\hline Yes & $4(13.3)$ & $26(89.3)$ & \multirow[b]{2}{*}{0.47} \\
\hline No & $19(7.1)$ & 235 (92.9) & \\
\hline
\end{tabular}


Table 6. Distribution of deaths in TB patients according to their paraclinical results in two anti-TB treatment centers in Dakar: 2019-2020 $(\mathrm{N}=282)$.

\begin{tabular}{|c|c|c|c|}
\hline \multirow{2}{*}{ Paraclinical data } & \multicolumn{2}{|c|}{ Death } & \multirow{2}{*}{$\mathrm{p}$} \\
\hline & Yes n (\%) & No n (\%) & \\
\hline \multicolumn{4}{|l|}{ Chest X-ray } \\
\hline Normal & $3(8.1)$ & $34(91.9)$ & - \\
\hline Abnormal & $14(9.3)$ & $136(90.7)$ & 0.81 \\
\hline Not done & $5(5.3)$ & $90(94.7)$ & 0.54 \\
\hline \multicolumn{4}{|c|}{ Microscopy for acid fast bacilli } \\
\hline Negative & $8(7.5)$ & $99(92.5)$ & - \\
\hline Positive & $7(5.8)$ & $113(94.2)$ & 0.62 \\
\hline Not done & $7(12.7)$ & $48(87.3)$ & 0.28 \\
\hline \multicolumn{4}{|l|}{ Gen Xpert } \\
\hline Negative & $1(5)$ & $19(95)$ & - \\
\hline Positive & $5(12.5)$ & $35(12.5)$ & 0.37 \\
\hline Not done & $16(7.2)$ & $206(92.8)$ & 0.71 \\
\hline \multicolumn{4}{|l|}{ Hyperleukocytosis } \\
\hline Yes & $6(23.1)$ & $20(76.9)$ & \multirow[b]{2}{*}{0.009} \\
\hline No & $16(6.2)$ & $240(93.8$ & \\
\hline \multicolumn{4}{|l|}{ Severe anemia } \\
\hline Yes & $16(16.5)$ & $81(83.5)$ & \multirow[b]{2}{*}{$<0.001$} \\
\hline No & $6(3.2)$ & $179(96.8)$ & \\
\hline \multicolumn{4}{|l|}{ Thrombocytopenia } \\
\hline Yes & $3(17.6)$ & $14(82.4)$ & \multirow{2}{*}{0.14} \\
\hline No & $19(7.2)$ & $246(92.8)$ & \\
\hline \multicolumn{4}{|l|}{$\mathrm{CRP}>24 \mathrm{mg} / \mathrm{l}$} \\
\hline Yes & $19(7.3)$ & $240(92.7)$ & \multirow{2}{*}{0.4} \\
\hline No & $3(13)$ & $20(87)$ & \\
\hline \multicolumn{4}{|l|}{ Severe hyponatremia } \\
\hline Yes & $7(18.4)$ & $31(81.6)$ & \multirow{2}{*}{0.02} \\
\hline No & $15(6.1)$ & $129(93.9)$ & \\
\hline \multicolumn{4}{|l|}{$\mathrm{ALT}>45 \mathrm{IU} / 1$} \\
\hline Yes & $3(3.4)$ & $85(96.6)$ & \multirow[b]{2}{*}{0.11} \\
\hline No & $19(9.8)$ & $175(90.2)$ & \\
\hline
\end{tabular}


Table 7. Logistic regression assessing the associated factors with deaths in TB patients in two anti-TB treatment centers in Dakar: 2019-2020 $(\mathrm{N}=282)$.

\begin{tabular}{|c|c|c|c|c|c|}
\hline \multirow{2}{*}{ Variables } & & \multicolumn{2}{|c|}{ Univariate } & \multicolumn{2}{|c|}{ Multivariate } \\
\hline & & OR [95\% CI] & $\mathrm{p}$ & $\mathrm{aOR}[95 \% \mathrm{CI}]$ & $\mathrm{p}$ \\
\hline \multirow{3}{*}{ Age groups (Years) } & {$[16-40[$} & 1 & & & \\
\hline & {$[40-60[$} & $3.3[0.9-11.7]$ & 0.05 & $1.1[0.2-5.3]$ & 0.90 \\
\hline & $\geq 60$ & $7.55[2.0-28.3]$ & 0.003 & $26.2[3.6-191.2]$ & 0.001 \\
\hline \multirow{2}{*}{ Sex } & Female & 1 & & & \\
\hline & Male & $0.8[0.3-2.2]$ & 0.6 & $1.01[0.3-4.1]$ & 0.98 \\
\hline \multirow{2}{*}{ HIV infection } & No & 1 & & & \\
\hline & Yes & $9.55[3.0-30.3]$ & $<0.001$ & $7.2[1.4-36.9]$ & 0.02 \\
\hline \multirow{2}{*}{ Neurological localization } & No & 1 & & & \\
\hline & Yes & $13.5[4.7-38.8]$ & $<0.001$ & $13.2[3.2-54.3]$ & $<0.001$ \\
\hline \multirow{2}{*}{ Hyperleukocytosis } & No & 1 & & & \\
\hline & Yes & $2.6[0.6-9.7]$ & 0.15 & $2.4[0.5-12.6]$ & 0.28 \\
\hline \multirow{2}{*}{ Severe anemia } & No & 1 & & & \\
\hline & Yes & $7.2[2.3-22.7]$ & $<0.001$ & $5.5[1.3-23.9]$ & 0.02 \\
\hline Platelets (cells $/ \mathrm{mm}^{3}$ ) & & $0.9[0.9-0.99]$ & 0.004 & $0.99[0.9-1]$ & 0.05 \\
\hline
\end{tabular}

\section{Discussion}

During a one-year period, we followed $282 \mathrm{~TB}$ patients in three TB treatment centers in Dakar, which are in accordance with the national TB guidelines. The mortality rate was $7.8 \%$. All the potential explaining variables that were within our reach were taken into account in our analysis. Factors identified to be significantly associated with death after a multivariate analysis was: advanced age, HIV positive status, neurological localization of the TB, and severe anemia.

\subsection{The Mortality Rate}

The mortality rate $(7.8 \%)$ in our study is lower than the ones found in Africa and in Senegal in 2018 (25\% and 16\%, respectively) [2]. This mortality rate is also lower than the mortality rates found by Fortes Déguénonvo et al in Senegal in 2014 (31\%) [6], Diallo et al in Guinea Conakry in 2015 (14\%) [7] and Ade S et al in Benin in 2015 (12\%) [8]. However, it was higher than the one found by Diop $\mathrm{M}$ et al in Thies (Senegal) in 2014 (5.5\%) [9]. These differences may be related to the improvement of health care strategies and medical advances, medical facility differences from one health care center to another, and differences in the selection of study populations. The racial disparity of study populations in different countries in terms of sociocultural characteristics, TB exposure level, health care access may also explain these differences. 


\subsection{Associated Factors with Death}

\subsubsection{Advanced Age}

In our study, patients older than 60 years of age were 26 times more likely to die compared to patients who were between 16 to 40 . The link between advanced age with death is noted in almost all studies assessing risk factors of death among TB patients [10] [11] [12]. This association may be explained by the decrease of the immune system with advancing age and the occurrence of other fatal diseases related to advanced age. Rare studies have focused their analysis on the standardization of mortality in age groups and showed a significant increase of death in young patients [13].

\subsubsection{HIV Infection Status}

Our study shows that the probability of death was 7 times higher in HIV positive patients than in HIV negative patients. This finding is in line with results of many other authors such as Ohene SA et al in Accra (Ghana) [10] and Qian X et al in Texas [14]. Similar to advanced age, the association of HIV infection with death among TB patients may be due to the weakened immune system caused by HIV, decreasing the strength to fight against TB. This increased probability may also be due to other serious opportunistic infections associated with HIV that may contribute to the high mortality among HIV positive patients.

\subsubsection{Neurological Localization of TB}

The neurological localization of TB appeared to be independently associated with mortality in our study with an adjusted OR of 13.2 and a CI $95 \%$ of [3.2 54.3]. This result is similar to the findings of Ohene SA et al in Accra (Ghana), which showed a significant association between neurological localization of TB and death with an adjusted OR of 3.9 a CI 95\% of [1.1 - 13.2] [10]. In Senegal, a study dealing with patients infected both by tuberculosis and HIV showed a significant relationship between neurological localization of TB and death ( $\mathrm{p}<$ 0,001) [5]. Mechanic, vascular, inflammatory, and metabolic injuries caused by Koch's bacillus on the central nervous system makes this form of TB particularly serious and may contribute to an early death. Moreover, the difficulty in diagnosing neurological form of TB can contribute to late treatment onset and may explain frequent unexpected deaths of some patients.

\subsubsection{Severe Anemia}

TB patients who had severe anemia in our study had increased mortality rate compared to TB patients who did not (adjusted OR $=5.52$; CI 95\% [1.28 23.86]). This finding is consistent with those reported by a Russian study, which underlined that patients with anemia were 5 times more at risk to die compared to patients with normal hemoglobin level [15]. The same association was identified by Mugusi FM et al in Tanzania. They showed that a low hemoglobin rate was a predictor factor of death among TB patients (adjusted OR $=0.73$; CI 95\% $[0.67,0.80])[16]$. This association may be explained by the fact that anemia, mainly due to chronic inflammation from TB infection, increases vital organ 
failures such as heart, kidneys, or brain and contributes to mortality.

Some researchers have found other associated factors of deaths among TB patients such as female gender [17], low level of education [18], general ill health [16], and positivity or negativity of smear microscopy for acid fast bacilli [19] [20]. All these independent variables were taken into account in our analysis but did not appear to be significantly associated with mortality. These differences may be due to differences in study design, sample size, or study populations.

\subsection{Limitations of the Study}

Despite the results which are globally in line with those found in the literature, our study has some limitations. The first one link with the fact that the study dealt mainly with in-patients. This does not allow statistical inference to the general population. The second one is related to the relatively low sample size that may impact the strength of the study. The third one is that we could not take into account some factors, such as patients' economical status, their access to healthcare centers, their social and cultural characteristics, which have been significantly associated with deaths among TB patients in some studies [21] [22] [23]. Additionally, we were not able to clearly define the duration of the evolution of the symptoms among all patients, which may impact the treatment outcome [24].

\section{Conclusion}

This prospective study shows a lower mortality rate than what was recently estimated in Africa and Senegal. It also presents a number of factors, such as advanced age, HIV infection status, neurological localization of TB, and severe anemia that increase mortality rate among TB patients. Knowledge of these associated factors by physicians could improve the management of TB patients and reduce TB-related mortality. This may contribute to reaching the goals of "End TB" strategy by 2030.

\section{Acknowledgements}

We would like to acknowledge:

- Moustapha Diop, English Professor (Cass Cass high school, Senegal) for the language edits;

- Jiyeon Jeon, MD, MPH (Providence Seaside Hospital, OR, USA) for the language and technical edits.

\section{Conflicts of Interest}

The authors declare no conflicts of interest regarding the publication of this paper.

\section{References}

[1] World Health Organization (2018) Global Tuberculosis Report. Licence: CCBY-NC-SA 
3.0 IGO, World Health Organization, Geneva.

[2] World Health Organization (2019) Global Tuberculosis Report. Licence: CCBY-NC-SA 3. 0 IGO, World Health Organization, Geneva.

[3] Floyd, K., Glaziou, P., Houben, R., Sumner, T., White, R.G. and Raviglione, M. (2018) Global Tuberculosis Targets and Milestones Set for 2016-2035: Definition and Rationale. International Journal of Tuberculosis and Lung Disease, 22, 723-730. https://doi.org/10.5588/ijtld.17.0835

[4] Programme de lutte contre le Tuberculose (2018) Manuelle de lutte contre la tuberculose au Sénégal.

[5] Harouna, A.M.L., Doutchi, M., Amadou, O., Neino, M.A., Kadri, S., Garba, A. and Ndour, C.T. (2018) Facteurs Prédictifs de Décès au Cours de la Tuberculose Pulmonaire chez les Patients Vivant avec le VIH au CNHU Fann de Dakar. Health Sciences and Diseases, 20, 17-21.

[6] Déguénonvo, L.F., Diallo, V.C., Mbaye, K.D., Lakhe, N.A., Ka, D., Massaly, A., et al. (2017) Issues de traitement de la tuberculose à propos de 1030 cas traités dans un centre hospitalier universitaire au Sénégal. Médecine et Maladies Infectieuses, 47, 106-107. https://doi.org/10.1016/j.medmal.2017.03.262

[7] Diallo, B.D., Magassouba, A.S., Sobo, K.F., Camara, L.M. and Sow, O.Y. (2018) Étude des facteurs associés à la mortalité des malades tuberculeux pris en charge dans la ville de Conakry. Revue des Maladies Respiratoires, 35, A167-A168. https://doi.org/10.1016/j.rmr.2017.10.377

[8] Ade, S., Adjado, N., Dovonou, A.C., Ade, G., Anagonou, S. and Gninafon, M. (2018) Décès chez les patients tuberculeux traités dans le nord du Bénin: moment de survenue et facteurs associés. Revue des Maladies Respiratoires, 35, A182-A183. https://doi.org/10.1016/j.rmr.2017.10.418

[9] Diop, M.M., Touré, K., Bousso, S., Diop, M., Leye, A., Ndiaye, M., et al. (2019) Prévalence et Formes cliniques de la Tuberculose extrapulmonaire dans le district sanitaire de Thiès. Revue Africaine de Médecine Interne, 4, 6-9.

[10] Ohene, S.A., Bakker, M.I., Ojo, J., Toonstra, A., Awudi, D. and Klatser, P. (2019) Extra-Pulmonary Tuberculosis: A Retrospective Study of Patients in Accra, Ghana. PLoS ONE, 14, e0209650. https://doi.org/10.1371/journal.pone.0209650

[11] Waitt, C.J. and Squire, S.B. (2010) A Systematic Review of Risk Factors for Death in Adults during and after Tuberculosis Treatment. International Journal of Tuberculosis and Lung Disease, 15, 871-885. https://doi.org/10.5588/ijtld.10.0352

[12] Quy, H.T., Lonnroth, K., Lan, N.T. and Buu, T.N. (2003) Treatment Results among Tuberculosis Patients Treated by Private Lung Specialists Involved in a Public-Private Mix Project in Vietnam. International Journal of Tuberculosis and Lung Disease, 7, 1139-1146.

[13] Chiang, C.Y., Lee, J.J., Yu, M.C., Enarson, D.A., Lin, T.P. and Luh, K.T. (2009) Tuberculosis Outcomes in Taipei: Factors Associated with Treatment Interruption for 2 Months and Death. International Journal of Tuberculosis and Lung Disease, 13, 105-111.

[14] Qian, X., Nguyen, D.T., Lyu, J., Albers, A.E., Bi, X. and Graviss. E.A. (2018) Risk Factors for Extrapulmonary Dissemination of Tuberculosis and Associated Mortality during Treatment for Extrapulmonary Tuberculosis. Emerg Microbes Infect, 7, 1-14. https://doi.org/10.1038/s41426-018-0106-1

[15] Kourbatova, E.V., Borodulin, B.E., Borodulina, E.A., Del Rio, C., Blumberg, H.M. and Leonard Jr., M.K. (2006) Risk Factors for Mortality among Adult Patients with 
Newly Diagnosed Tuberculosis in Samara, Russia. International Journal of Tuberculosis and Lung Disease, 10, 1224-1230.

[16] Mugusi, F.M., Mehta, S., Villamor, E., Urassa, W., Saathoff, E., Bosch, R.J. and Fawzi, W.W. (2009) Factors Associated with Mortality in HIV-Infected and Uninfected Patients with Pulmonary Tuberculosis. BMC Public Health, 9, Article No. 409. https://doi.org/10.1186/1471-2458-9-409

[17] Abos-Hernandez, R. and Olle-Goig, J.E. (2002) Patients Hospitalised in Bolivia with Pulmonary Tuberculosis: Risk Factors for Dying. International Journal of Tuberculosis and Lung Disease, 6, 470-474. https://doi.org/10.5588/09640569512959

[18] Quy, H.T., Cobelens, F.G., Lan, N.T., Buu, T.N., Lambregts, C.S. and Borgdorff, M.W. (2006) Treatment Outcomes by Drug Resistance and HIV Status among Tuberculosis Patients in Ho Chi Minh City, Vietnam. International Journal of Tuberculosis and Lung Disease, 10, 45-51.

[19] Shen, X., Deriemer, K., Yuan, Z Xia, Z., Gui, X., Wang, L. and Mei, J. (2009) Deaths among Tuberculosis Cases in Shanghai, China: Who Is at Risk? BMC Infectious Diseases, 9, Article No. 95. https://doi.org/10.1186/1471-2334-9-95

[20] Connolly, C., Davies, G.R. and Wilkinson, D. (1998) Impact of the Human Immunodeficiency Virus Epidemic on Mortality among Adults with Tuberculosis in Rural South Africa, 1991-1995. International Journal of Tuberculosis and Lung Disease, 2, 919-925.

[21] Najera-Ortiz, J.C., Sanchez-Perez, H.J., Ochoa-Diaz, H., Arana-Cedeno, M., Lezama, M.S. and Mateo, M.M. (2008) Demographic, Health Services and Socio-Economic Factors Associated with Pulmonary Tuberculosis Mortality in Los Altos Region of Chiapas, Mexico. International Journal of Epidemiology, 37, 786-795.

https://doi.org/10.1093/ije/dyn089

[22] Barker, R.D., Nthangeni, M.E. and Millard, F.J. (2002) Is the Distance a Patient Lives from Hospital a Risk Factor for Death from Tuberculosis in Rural South Africa? International Journal of Tuberculosis and Lung Disease, 6, 98-103.

[23] Adjoh, K., Ouedraogo, G., Adambounou, S., Ouedraogo, A.R., Boukari, M. and Tidjani, O. (2017) Facteurs associés aux décès chez les tuberculeux en phase intensive du traitement au CHU Sylvanus Olympio de Lomé. Revue des Maladies Respiratoires, 34, A230-A231. https://doi.org/10.1016/j.rmr.2016.10.554

[24] Low, S., Ang, L.W., Cutter, J., James, L., Chee, C.B.E., Wang, Y.T. and Chew, S.K. (2009) Mortality among Tuberculosis Patients on Treatment in Singapore. International Journal of Tuberculosis and Lung Disease, 13, 328-334. 


\section{Appendix}

\section{CRF}

1) SOCIO-DEMOGRAPHIC DATA

Patient Code:

Day of admission:

In-patient: Yes $\square$ No $\square$

Department: DITD*/DPH ${ }^{* *} \square$ DITD/FANN HOSPITAL $\square$

\section{PULMONOLOGY/DPH}

Initial of first Name

Initial of second Name

Address:

Sex: Age: $\left|\_\right| \ldots \mid$ years

Profession:

Marital status: Single $\square$ Married $\square$ Divorced $\square$ Widowed $\square$

School attendance: Yes $\square$ No $\square$

Educational level: Primary $\square$ Secondary $\square$ University $\square$

2) BACKGROUNDS-LIFESTYLE

$>$ Backgrounds

TB contact: Yes $\square$ No $\square$ History of TB: Yes $\square$ No $\square$

High blood pressure: Yes $\square$ No $\square$ Diabetes: Yes $\square$ No

HIV: Yes $\square$ No $\square$ Others: Yes $\square$ No $\square$ if others, precise:

\section{Lifestyle}

Alcohol consumption: Yes $\square$ No $\square$

Smoking: No $\square$ Former smoker $\square$ current smoker $\square$

3) CLINICAL DATA

$>$ Functional signs:

The beginning of symptoms: (days or months)

Coughing:Yes $\square$ No $\square$ Chest pain:Yes $\square$ No $\square$

Dyspnea:Yes $\square$ No $\square$ Vomiting:Yes $\square$ No $\square$

Headaches: Yes $\square$ No $\square$ Hemoptysis: Yes $\square$ No $\square$

Others: Yes $\square$ No $\square$ If others, precise

Vital signs:

Temperature: $\left|\_\right| \_|\cdot| \_\mid$Weight: $\left|\_\right| \_\left|\_\right|$kg Size: $\left|\_\right| \cdot\left|\_\right| \_\mid \mathrm{m}$ Blood Pressure: |/_____ $\mathrm{mm} \mathrm{Hg}$

Respiratory rate: $\mathrm{c} / \mathrm{min}$

Pulse:

$>$ General signs:

Long term fiver: Yes $\square$ No $\square$

Weight loss: Yes $\square$ No $\square$

Weakness: Yes $\square$ No $\square$

Loss of appetite: Yes $\square$ No $\square$

$>$ Examination:

pulmonary condensation: Yes $\square$ No $\square$

lymphadenopathy: Yes $\square$ No $\square$ if yes, Localization:

Pleurisy: Yes $\square$ No 
Pneumothorax: Yes $\square$ No $\square$

meningeal syndrome: Yes $\square$ No $\square$

Other neurological signs: Yes $\square$ No $\square$ if yes, precise:

Ascites: Yes $\square$ No $\square$

Other signs: Yes $\square$ No $\square$ If yes, precise:

4) PARACLINICAL INVESTIGATIONS

Bacteriological investigations

Smear microscopy done: Yes $\square$ No $\square$

Results of Smear microscopy: positive $\square$ Negative $\square$

Specimen: Gastric lavage: Yes $\square$ No $\square$

Smear: Yes $\square$ No $\square$

Urines: Yes $\square$ No $\square$

Lymph node puncture: Yes $\square$ No $\square$

Broncho-alveolar lavage fluid: Yes $\square$ No $\square$

Others: Yes $\square$ No $\square$

If yes, precise

Gen Xpert done: Yes $\square$ No $\square$

Results: positive $\square$ negative $\square$

Specimen: Gastric lavage: Yes $\square$ No $\square$

Smear: Yes $\square$ No $\square$

Urines: Yes $\square$ No $\square$

Lymph node puncture: Yes $\square$ No $\square$

Broncho-alveolar lavage fluid: Yes $\square$ No $\square$

Others: Yes $\square$ No $\square$

If yes, precise

\section{Cells blood Count}

Hemoglobin rate: $\left|\_\right| \ldots|.| \ldots \mid g / d l$

Mean corpuscular volume: |_______ $|$.$| _ \mid \mathrm{fl}$

White blood cells: $\mid$

Red blood cells: $\mid$

Platelets: |___________ $\mid / \mathrm{ml}$

Lymphocytes: $\mid$

Neutrophils: |__________ $\mid / \mu \mathrm{L}$

\section{Blood biochemistry}

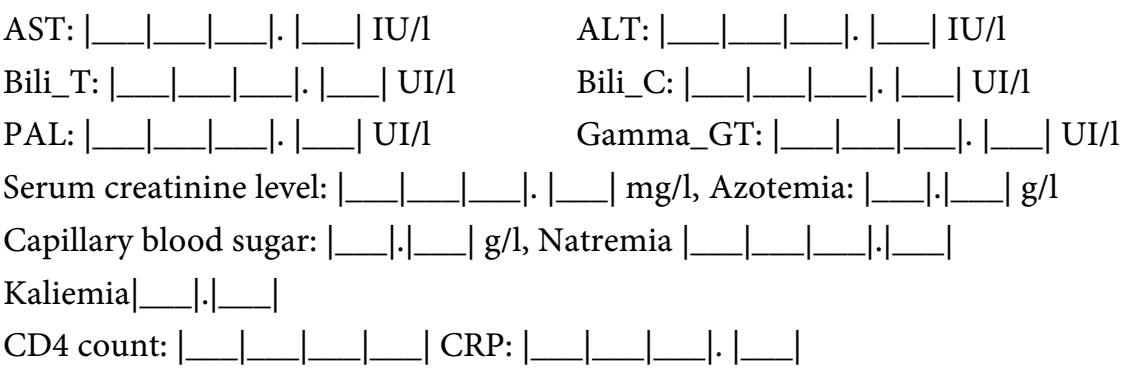

Chest X-ray: Normal $\square$ Abnormal $\square$ Not done $\square$

Precise abnormalities: alveolar sd $\square$ interstitial sd $\square$ 
alveolointertitial sd $\square$ pleural infusion $\square$

miliary $\square$ cavitation $\square$

pneumothorax $\square$ lymphadenopathies $\square$ other signs $\square$, precise

$>$ Chest CT scan: Normal $\square$ Abnormal $\square$ Not done $\square$

Precise abnormalities: alveolar sd $\square$ interstitial sd $\square$ alveolointertitial sd $\square$

pleural infusion $\square$ miliary $\square$ cavitation $\square$

pneumothorax $\square$ lymphadenopathies $\square$

other signs $\square$ if yes, precise

Abdominal CT scan: Normal $\square$ Abnormal $\square$ Not done $\square$

Precise abnormalities: Lymphadenopathy $\square$ Ascites $\square$

Other signs: $\square$, If other signs Precise:

5) TB CLASSIFICATIONS

Final diagnosis: New case $\square$ relapse case $\square$ treatment re-starting case $\square$

TB categories: IPT $\square$ IET $\square$ Pulmonary + extrapulmonary TB $\square$

Extrapulmonary localizations:

pleural $\square$

splenic $\square$

pericardial $\square$

peritoneal $\square$

lymph node $\square$

neurological $\square$

articular bone $\square$

urogenital tract $\square$

hepatic $\square$

Other localizations $\square \quad$ if other localizations, precise

Confirmed TB: Yes $\square$ No $\square$

If yes: by microcopy $\square$ by Gen Xpert $\square$ by culture $\square$

6) TREATMENT DATA

$\checkmark$ Anti-TB drugs:

Date de of starting: $|\ldots|$

Treatment regimen:

Number of tablets:

$\checkmark$ OTHER TREATMENT:

\section{7) EVOLUTION DATA}

Hospital stay days: (days)

Control after one month of treatment (M1)

Smear microcopy: Done $\square$ Not done $\square$. Results: Positive $\square$ Negative

Control after 5 month of treatment

Smear microcopy: Done $\square$ Not done $\square$. Results: Positive $\square$ Negative $\square$

Treatment outcomes: Success $\square$ Failure $\square$ loss of follow-up $\square$ Dead

Transferred $\square$

${ }^{*}$ Department of Infectious and Tropical Diseases

${ }^{*}$ Dakar Principal Hospital 